Studia Anglica Posnaniensia 51/3, 2016

doi: 10.1515/stap-2016-0013

\title{
THE VISUAL TEXT: BIBLIOGRAPHIC CODES AS PRAGMATIC MARKERS ON A MANUSCRIPT PAGE
}

\author{
JUSTYNA ROGOS-HEBDA*
}

Faculty of English, Adam Mickiewicz University in Poznań

\begin{abstract}
${ }^{1}$
This paper explores the dynamics of the textual-visual interface of a medieval manuscript page within the frameworks of historical pragmatics and pragmaphilological approaches to the study of historical texts. Whilst the former focuses on the contexts in which historical utterances, manifested as texts, occur (Jacobs \& Jucker 1995: 11), the latter involves a context-based perspective in the study of individual historical texts (Jucker 2000: 91). Combining the two approaches allows for a more comprehensive study of the "visual text" (cf. Machan 2011) than has been possible for paleographic, codicological, or linguistic analyses of medieval manuscripts. The present paper adopts the "pragmatics-on-the-page" approach (cf. Carroll et al. 2013, Peikola et al. 2014) in its analysis of bibliographic codes in British Library Royal MS 18 D II, which contains the texts of Lydgate's Troy Book and Siege of Thebes. Such visual elements of the manuscript page as mise en page, ink colour, as well as type and size of script will be examined as pragmatic markers, functioning on three levels of meaning: textual, interactional, and metalinguistic (cf. Erman 2001, Carroll et al. 2013), and providing (visual) contexts for interpreting the linguistic message of the text.
\end{abstract}

Key words: visual pragmatics, Middle English manuscript, pragmatics of the page, mise en page

\section{Introduction: Medieval manuscript as a visual text}

All texts are inherently visual: before we decode the linguistic message inscribed within the graphic (or alphabetic) symbols, we perceive the shapes,

Faculty of English, Adam Mickiewicz University, al. Niepodległości 4, 61-874 Poznań, Poland,jrogos@wa.amu.edu.pl

1 This paper is based on the author's post-doctoral project "Latin abbreviations in Middle English literary manuscripts: evolution of forms and functions" (UMO2012/05/B/HS2/03996), supported by Polish National Science Centre. 
sizes, and colours of the letters and their arrangement on the page. The visuality of the text is reinforced by bibliographic codes that break the familiar linearity of the textual layer, such as changes in font type and size, shifts in the arrangement of text columns on the page, or the superimposition of nonalphabetic symbols onto a string of letters. This inherent visuality was also a defining feature of manuscript culture, with the manuscript page requiring from the reader negotiating a number of mutually dependent graphic elements: letter shapes and sizes, ink colours, rubrics, running heads, marginal comments, catchwords, images, abbreviation symbols, etc., the sum of which totalled the meaning of the text (or page). As argued by Carroll et al. (2013: 55), the visual elements of the historical text influence its meaning in manners comparable to the impact that the social or situational context have on historical spoken interactions (as mediated through written records) and so the appearance of the page is "crucial to the [medieval] reader's construal of meaning". Thus, the manuscript communicates to the reader through an interaction of text and image on the one hand, and, on the other, through the organisation of visual content on the page (Jucker \& Pahta 2013: 3).

\section{Visual pragmatics}

Rapid development of digital humanities has revealed the need for a partial reorientation of scholarly approaches to the study of historical texts: integrating the methodology of traditional humanities with tools linked with computing and digital publishing has not only allowed an unprecedented access to medieval manuscripts in the digitised format (not infrequently accompanied by an elaborate electronic descriptive-analytical apparatus) but it also highlighted the importance of the visual contexts of historical texts. Access to digitised images, created, maintained and analysed via computing tools also enabled a broader application of historical pragmatic methods to "reconstruct patterns of correspondence between communicative functions and visual forms and contextual reasons for selection between alternative forms" (Carroll et al. 2013: 56). Expanding the investigative perspective, traditionally oriented towards palaeography and codicology, towards a more inclusive, interdisciplinary approach (i.e., one combining the tools and methods of book history, manuscript studies, traditional philology, historical pragmatics and discourse analysis) permits a better understanding of the ways in which medieval readers made sense of the manuscript page. This relatively new field of inquiry is visual pragmatics, or pragmatics of the page, which centres on the manuscript page as the object of study. The text, i.e., "a concrete instance of writing" (or print, for that matter), "generated by producers of texts (from authors to printers) in specific communicative 
settings, to serve the needs of specific consumers" (Carroll et al. 2013: 6667), functions as an "utterance" in the visual pragmatic analysis. Such analysis focuses on graphic elements on the manuscript page in their functional contexts (or, in the pragmatic terminology, functional domains). From this perspective, visual cues such as colour of the ink, size and type of script, punctuation or abbreviations are equivalent to pragmatic markers, aiding the communicative effectiveness of manuscript discourse. The following part of this paper will examine the functional domains of selected visual-pragmatic markers in BL Royal MS 18 D II, containing Lydgate's Troy Book and Siege of Thebes as an aid in a better understanding of the mechanics of the visual text (cf. Machan 2011).

\section{Context: Royal MS 18 D II as a socio-historical and cultural object}

British Library Royal MS 18 D II is a mid-fifteenth-century parchment codex, containing John Lydgate's Testament, Siege of Thebes, and Troy Book, alongside verses by William Cornish, John Skelton, William Peeris and other minor pieces. Folios $1 \mathrm{v}-5 \mathrm{r}$ are occupied by Lydgate's Testament; ff. $6 \mathrm{r}-146 \mathrm{r}$ contain his Troy Book; ff. 147v-162r - Siege of Thebes, whereas on ff. 163r$211 \mathrm{v}$ one can find the remaining texts. The current study focuses on the two longer pieces by Lydgate. The manuscript in question is visibly a de luxe copy, adorned with a series of miniatures in colour and gold, foliate borders and initials in gold with penwork decoration, as well as occasional cadels (i.e., decorative extensions to the ascenders of the letters) and rubrics. Initial letters at the beginning of the line are on most folios marked in red or gold. The texts of both Siege of Thebes and Troy Book are written in elegant cursive hands of the Anglicana, secretary, and hybrid types, arranged in two columns of $+/-50$ lines. The text was written by several hands, one of which was identified in a quire of another Lydgate manuscript in the Bodleian Library. The visual structure of the codex highlights its prestigious status: the manuscript was meant as a presentation copy for Henry VI from Sir William Herbert, $1^{\text {st }}$ earl of Pembroke, and his wife Anne Devereux (represented on the miniature at f. 6r).

\section{Visual elements as pragmatic markers}

In Twyman's (1998: 32) words, texts, especially historical ones, "articulate visually", through the mediation of scribes, illuminators, rubricators, bookbinders or, later, printers. It is first and foremost through visual elements that manuscripts communicate their contents to the reader. Therefore, ultimately, every visual aspect of a medieval manuscript page serves as a pragmatic marker in the sense that it supports the interaction between the text 
and its reader, as well as organises and monitors "manuscript discourse". Thus, visual cues found on a manuscript page facilitate communication between the text (or its author/scribe) and the reader on three pragmatic levels: textual, interactional/social and metalinguistic/stance (cf. Erman 2001: 1339, Carroll et al. 2013: 65).

At the textual level, pragmatic markers organise discourse, creating textual coherence (Erman 2001: 1340). This is a "text-oriented" function. From the visual-pragmatic point of view, in their textual-monitoring function, such bibliographic codes as variations in colour of the ink, type and size of script, or the application of abbreviations, help the scribes arrange their mise en page. For instance, the use of red ink emphasises shifts from the vernacular to Latin, whilst ornamental capitals herald the beginning of a new section in the text. Those same markers, however, also serve the interactional/social, or readeroriented function: they help the reader navigate the text, which Erman refers to as "a comprehension-securing function" (Erman 2001: 1340). To exemplify, the narrative in the Book of Troy MS is often interrupted with rubricated summaries of the upcoming sections of the text to help the reader follow the text more efficiently. Finally, what Erman (2001: 1339) calls "metalinguistic function" and Carroll et al. (2013: 65) describe as "stance level", in the context of a manuscript text can be described as an author/scribe-oriented function of pragmatic markers. At this level, such markers are used to "inform the addressee about the [author's] commitment to the truth of the proposition or judgement of the importance or value of what is being communicated" (Erman 2001: 1339). This function is roughly equivalent to epistemic stance, in that the authors/scribes employ visual signals to emphasise their "evaluative judgements" (Carroll et al. 2013: 64) about their text(s). Those judgements find their visual expressions, for instance, in the choice of the mise en page (e.g., single vs. double columns) or referencing other authors within the text.

The following discussion will focus on the visual-pragmatic markers in Lydgate's Troy Book and Siege of Thebes in BL Royal MS 18 D II, i.e. on "anything on the page that adds meaning to the linguistic message" (Carroll et al. 2013: 56). Visual components, such as mise en page, ink colour, variation in script type and size will be considered alongside two visual-linguistic elements attested on manuscript pages, namely code switching and abbreviations, so as to explore their functional domains and unpack the dynamics of the visual text.

\subsection{Mise en page}

On the textual level, the layout of individual pages serves the function of organising manuscript discourse. The text of both Troy Book and Siege of Thebes is arranged in two columns by means of carefully executed grids of 
guide lines in black ink - the same colour as that of the main text. The ruled columns outline the writing space for the scribes, whereas occasional corrections/insertions (e.g., f. 13r), catchwords (e.g. f. 13v), or - in the Siege of Thebes - rubricated section headings are relegated to the margins. The margins are also 'display windows' for purely decorative elements: the penwork of foliate initials or cadels, which are kept distinct from the main text. Mise en page in BL Royal MS 18 D II also functions as a discourse marker in that it signals transitions between individual chunks of discourse (Erman 2001: 1340). For instance, at f. 66r, the end of Book Two of Troy Book is signalled by two empty lines beneath the main text, underneath which an explicit in a different type and size of script was added. The beginning of Book Three, in turn, coincides with the beginning of f. $66 \mathrm{v}$ and is highlighted by means of a miniature, foliate borders, and a rubricated incipit. Encoding and editing the text with a view to ensuring an appropriate form of the communicative situation is yet another manifestation of the textual function of pragmatic markers, which in the manuscript under consideration is performed by page layout. The doublecolumn frame, the foliate borders and miniatures on opening pages of new parts of the text, the rubrics and champ initials signalling the beginning of new sections of the text all add to the prestige to the manuscript.

The main purpose of mise en page in its interactional function is to facilitate the reading experience. Repetitive patterns into which visual elements on manuscript pages are arranged ensure an unproblematic navigation through the Troy Book and Siege of Thebes: the narrative is contained within the text frame, but all the other visual pragmatic markers performing the social function operate "outside the text proper" (Erman 2001: 1340). Additions and decorations extend to the margins, whereas additional explanatory/descriptive material is separated from the main text through rubrication or/and shift to the margins.

Finally, also the stance of the author is manifested in the mise en page, which can be interpreted from the perspective of the metalinguistic or (more appropriately for the present context) metatextual function. It has already been mentioned that elements of the mise en page emphasise the prestige of the codex in question. To mention just two examples, arranging the text in double columns may have been meant to add authority to the text, since the same kind of layout was encountered in biblical manuscripts, whereas heralding the beginnings and endings of subsequent parts of the works in Latin both added to the authority of the text and inscribed it within a broader tradition of Latinbased literacy. 


\subsection{Ink colour and pigments}

The scribes of BL Royal MS 18 D II use a number of colours for organising their textual discourse: two colours of ink for writing the text and additional pigments for decorated and highlighted initials. In the former context, the main text, along with explicits in Latin, is written in black or brownish ink, whereas red ink is used for brief summaries/titles, which herald the opening of a new section of the text. Those sections begin with large champ initials: golden letters against a background of pink and blue, spreading over two, three or four lines, with foliate penwork decoration extended beyond the ruled column of text. Smaller subsections of the text, in turn, are initiated by blue initials with pink penwork. This colour scheme performs the visual-pragmatic function by signposting the 'turn-taking' in the communicative context of the manuscript: the red of the rubrics, introducing section summaries; the gold, blue, and pink of the initials announcing new sections of the material; and the black or brown of the main text all reinforce the information structure of the manuscript page. The colours of the letters also help the reader navigate the text more efficiently: large foliate initials indicate the beginning of a new book, and rubrics and champ initials - a new section of the text. Thus, in their social pragmatic function, colours in BL Royal MS 18 D II, "ascertain or elicit audience involvement" (Erman 2001: 1340). As markers of stance, in turn, they are the scribes' commentary on the importance and truth-value of the text (the use of expensive gold and lapis azuli for initials and miniatures highlights the importance and authority of the work).

\subsection{Script type and size}

Both Troy Book and Siege of Thebes in BL Royal MS 18 D II were copied by a few scribes, all of whom used a variety of Gothic cursive script, ranging from Anglicana through hybrid to secretary types. The ductus has a vertical aspect, with very little slanting, and generous space is left both above and below the x-height (ascenders rarely reach the top line, and descenders are only minimally traced below the bottom one). The size of script and hand type remain constant for both the main text and rubricated fragments, which adds to the coherence of the text, thus fulfilling the textual function of script as a pragmatic marker. It is only for explicits (e.g., f.66r, f.154v) that the scribes introduce variation within the two script-related parameters, but this variation fits in with the discourse-organising role of the script, since it signals visually shifts between individual chunks of discourse. Thus, explicits can be rubricated (e.g. f.148r), or, when written with the same ink as the main text, their script is larger and made to look somewhat more formal (e.g. f.66r). Not only does this variation in the visual aspect of the elements in question mark their distinct textual-structural function, but it also highlights a change in the linguistic code, 
from English to Latin. Even though the scribes of the Troy Book and Siege of Thebes take pains to emphasise visually the prestige and authority of their manuscript text, they do not employ the most formal type of script for their work, i.e. the formata-type, found in religious texts of the highest status, usually written in Latin. Applying that type of script to a popular work, however, would disturb the interactional function of this pragmatic marker, as the compactness and angularity of the formata-type of script makes it quite difficult to read.

\section{Conclusions}

The foregoing analysis has hopefully outlined the potential in, and, indeed, the need for pragmatic analysis of visual components of the manuscript page. Since all communication is context driven, due consideration should also be ensured for the visual contexts of communication in historical texts. It needs to be emphasised that historical pragmatics can reach beyond teasing out from the written text features of spoken discourse and identifying pragmatic markers which organise that discourse in the historical-linguistic context. One can only understand (historical) textuality when looking through an interdisciplinary lens of traditional manuscript studies and historical pragmatics and pragmaphilology. It has been argued here, as has already been argued elsewhere (cf. Peikola et al. 2014, Carroll et al. 2013) that historical handwritten texts can be studied both as linguistic and visual objects, i.e., as visual texts (cf. Machan 2011). It is then possible to account better for the inherent variability of the visual and textual elements of the manuscript page by recourse to the communicative context, i.e., through the study of the pragmatic aspects of the manuscript page.

Mise en page, ink colours, type and size of script, alongside other visual elements, not discussed in the present paper, function as pragmatic markers in a medieval manuscript, organising discourse, ensuring reader's involvement, and establishing authorial/scribal stance on the text $\mathrm{s} / \mathrm{he}$ has written. It is arguably through operating via the pragmatics-on-the-page, i.e., an integrated framework, that we can understand better the "information structure" of the communicative event that is the manuscript (visual) text. The present paper has only scratched the surface of what is a promising and constantly developing field of research. The potential offered by an interdisciplinary approach to historical texts will, however, generate more studies more comprehensive than the one sketched by the present author. 


\section{REFERENCES}

\section{PRIMARY SOURCES}

British Library MS Royal D II $18<$ http://www.bl.uk/manuscripts/FullDisplay.aspx?ref=Royal_MS_18_d_ii >

\section{SECONDARY SOURCES}

Carroll, Ruth, Matti Peikola, Hanna Salmi, Mari-Lisa Varila, Janne Skaffari \& Risto Hiltunen. 2013. Pragmatics on the Page. Visual text in late medieval English books. European Journal of English Studies 17.1. 54-71.

Erman, Britt. 2001. Pragmatic markers revisited with a focus on "you know" in adult and adolescent talk. Journal of Pragmatics 33.9. 1337-1359.

Jacobs, Andreas \& Andreas H. Jucker. 1995. Introduction. In Andreas H. Jucker (ed.), Historical pragmatics: Pragmatic developments in the history of English, 3-33. Amsterdam and Philadelphia: John Benjamins.

Jucker, Andreas H. 2000. English historical pragmatics: Problems of data and methodology. In Gabriella di Martino \& Maria Lima (eds.), English diachronic pragmatics, 17-55. Napoli: CUEN.

Jucker, Andreas H. \& Päivi Pahta. 2011. Communicating manuscripts: Authors, scribes, readers, listeners and communicating characters. In Päivi Pahta \& Andreas H. Jucker (eds.), Communicating early English manuscripts, 3-10. Cambridge: Cambridge University Press.

Machan, Tim William. 2011. The visual pragmatics of code-switching in Late Middle English literature. In Herbert Schendl \& Laura Wright (eds.), Code-switching in early English, 303-333. Berlin and Boston: Mouton de Gruyter.

Peikola, Matti, Mari-Liisa Varila, Carla Suhr, Janne Skaffari, Hanna Salmi, Aleksi Mäkilähde, Risto Hiltunen \& Ruth Carroll. 2014. Pragmatics on the Page (PoP).

$<$ https://www.utu.fi/en/units/hum/units/English/research/projects/Pages/Pragmatics-onthe-Page.aspx>

Twyman, Michael. 1998. The British Library guide to printing: History and techniques. London: The British Library. 